\title{
Application of Frequency Ratio Method for Landslide Susceptibility Mapping in the Surkhob Valley, Tajikistan
}

\author{
Shakhloi Mukhammadzoda ${ }^{1 *}$, Faizulloev Shohnavaz², Oimuhammadzoda Ilhomjon², \\ Guangcheng Zhang1 \\ ${ }^{1}$ Faculty of Geological Engineering, China University of Geosciences, Wuhan, China \\ ${ }^{2}$ Institute of Geology, Earthquake Engineering and Seismology, National Academy of Sciences of Tajikistan, Dushanbe, Tajikistan \\ Email: *shahlo200689@mail.ru
}

How to cite this paper: Mukhammadzoda, S., Shohnavaz, F., Ilhomjon, O., \& Zhang, G. C. (2021). Application of Frequency Ratio Method for Landslide Susceptibility Mapping in the Surkhob Valley, Tajikistan. Journal of Geoscience and Environment Protection, 9, 168-189.

https://doi.org/10.4236/gep.2021.912011

Received: September 27, 2021

Accepted: December 26, 2021

Published: December 29, 2021

Copyright $\odot 2021$ by author(s) and Scientific Research Publishing Inc. This work is licensed under the Creative Commons Attribution International License (CC BY 4.0).

http://creativecommons.org/licenses/by/4.0/ (c) (i) Open Access

\begin{abstract}
In the valley of the Surkhob River, manifestations of modern geological processes, characterized by various forms of manifestation, are widely developed. Studying these processes is of utmost importance, primarily landslides, which are directly related to the loss of stability of rocks on the slopes. Landslide processes in the Surkhob River valley, regardless of their type, cause significant economic damage to the population and the economy, as well as negatively impacting human living conditions. The primary goal of this project is to map landslide susceptibility using a geographic information system and quantitative and semi-quantitative methods. Landslide susceptibility assessment of this research was conducted using slope (degree), aspect of the slope, curvature, stream power index, topographic wetness index, precipitation and altitude. Except for precipitation, which was collected from the world climate site, most of the causal elements were derived from DEM from the SRTM (Shuttle Radar Topography Mission) database, with cell sizes of 30 m. 416 landslides were discovered from satellite pictures of Google Earth Pro and then validated in the field to analyses the link between causative factors and landslide inventory. To measure the weights of each causal element, the frequency ratio (FR) and the analytical hierarchy process (AHP) were used. The quality of the landslide susceptibility map was determined using the Receiver Operating Characteristics curve (ROC), and the AUC value was determined to be 0.877 . It is possible to use the landslide susceptibility map as an engineering and geological basis for establishing a national economic development plan for the territory of the Surkhob River valley.
\end{abstract}

\section{Keywords}

Component, Formatting, Style, Styling 


\section{Introduction}

One of the main directions of the economic development of Tajikistan is the development of territories with unfavorable engineering and geological conditions. Improving environmental protection, strengthening work on the preservation of agricultural land and ensuring the protection of lands from landslides is urgent issue. Such territories include the valley of the Surkhob River, which is subject to the intense impact of the landslide process. The Surkhob River valley is located in a zone of continuous landslide development, the causes of which are geological, tectonic, seismological, hydrogeological, and climatic factors.

The right of Surkhob River valley is composed of metamorphic and magmatic Proterozoic and Paleozoic rocks that are separated into blocks. Meso-Cenozoic sedimentary strata form a complex fold-ruptured structure on the left side. Vakhsh thrust as a complexly constructed folded-thrust zone, covering the entire southern flank of the river valley. Surkhob to the watershed of the Peter the Great ridge has a distinct geological structure in the valley of the Surkhob River landslides and are common in areas where Cretaceous and Quaternary sediments develop.

The deposits of Cretaceous system are widely developed within the Peter the Great ridge, less spreading of the Karategin ridge. The thickness of the chalk and its subdivisions in different parts of the study area varies in large intervals from $1000 \mathrm{~m}$ in the Karategin ridge to $2300 \mathrm{~m}$ in the Peter the Great ridge. In the Karategin ridge, chalk deposits are composed of red, brown sandy conglomerates, red coarse-grained sandstones, limestones, silts, and less often clays. In the Peter, the Great Ridge Cretaceous deposits are usually exposed in the cores of anticlinal structures that consist of red-colored sandy-clayey sediments. Also in the chalk section, brown clays with interlayers of gray, marly clays predominate. In the Karategin ridge, the section of the Cretaceous sediments in places begins with calcareous sandstones with interlayers of gray and brown clays. In the Peter the Great ridge, sometimes a sharp predominance of limestones is observed. In the section of the Cretaceous deposits, there is also an alternation of gray clays, gypsum with interlayers of clayey limestones. In the Cretaceous deposits, there are clearly pronounced recumbent folds with a horizontal position. Cretaceous deposits of the northern slope of the Peter the Great ridge have a characteristic relief, where landslides (Figure 2), ditches and scarps are widespread, which are located at different hypsometric levels, forming a series of steps, often inclined to the northeastern direction. The northern slope of the Peter the Great ridge has a characteristic landslide morphology, where landslides consist of Upper Cretaceous shales and limestones, 250 - $300 \mathrm{~m}$ thick.

In the valley of the Surkhob River formations of the Quaternary system are represented by gravel conglomerates, gravely and sandstones. There is a pebble-conglomerate stratum with a member of loam and sandy loam. Pebbles of conglomerates are cemented by loose sandy-calcareous material and consist of granites, porphyrites, limestones, sandstones and crystalline shales. Loess with a 
thickness of 40 - $50 \mathrm{~m}$ occurs on up to the Middle-Quaternary formations. Numerous large and small landslides on the right side of the Surkhob River are associated with the outflow of these loess deposits (Figure 3). Pebbles, which consist of fragments of various Paleozoic and Mesozoic-Cenozoic rocks, are found on the high basement terraces of the Surkhob River and are covered with loess-like loams. Modern deposits of the Quaternary system are represented by floodplain and channel alluvium of rivers. Proluvial deposits form small fanning cones and are composed of pebble and loamy-clayey material. They are often mixed with diluvial fine earthy clastic material.

The tectonic activity of the Surkhob River valley in the modern era is associated with the high seismicity of this region. The general nature of the geological structures makes it possible to assume that the thrusting processes continue to the present time. In the study area, the manifestation of landslide processes is associated with the impact of the internal forces of the earth, primarily by an earthquake. Tajikistan is characterized by high seismic activity, where more than 30 earthquakes with high amplitude have been recorded over the past century. It was found that earthquakes of weak and strong nature affect the activity and frequency of landslide processes (Evans et al., 2009).

Tectonically, the Surkhob River valley is located in the upper part of the Tajik basin. The Tajik basin marks the westernmost extent of the Indo-Asian collision zone which has been separated from the formerly connected Tajik-Tarim basins by the northward indentation of the Pamir plateau (Burtman \& Molnar, 1993; Schwab et al., 2004; Yin \& Harrison, 2000). It's a retro-foreland basin of Mesozoic-Cenozoic strata, which has a south-eastward thickening tendency (Burtman \& Molnar, 1993; Carrapa et al., 2015). To the north and west, the intramountain Tajik basin is divided from the Tian Shan by the dextral transpressive Illiac fault zone which father to the east translates into Vakhsh thrust system (Chapman et al., 2017; Kufner et al., 2018). To the east, the sinistral transpressive Darvaz fault zone which separates Tajik basin from the Pamir orogen, is assumed to have accommodated a significant northward offset of the Pamir relative to the Tajik basin, while to the south and southeast it borders with Hindu Kush (Burtman \& Molnar, 1993).

Several well-developed thrusting, sinistral strike-slip, and normal faults exhibit significant seismic deformation and crustal shortening, highlighting east-west extension and north-south shortening (Kufner et al., 2018; Metzger et al., 2020). The Darvaz and Vakhsh fault zones accommodate significant sinistral shear $(\sim 15 \mathrm{~mm} / \mathrm{yr})$ between the northward moving Pamir and the Tajik Depression, resulting in the NW-SE shortening and southwestward material flow out of the Peter the First Range into the Tajik Depression (Metzger et al., 2020; Mohadjer et al., 2010). While the eastern Pamir and the Tarim Basin move northward with negligible shear, the western Pamir advances both north and west involving lateral extrusion of material from the Pamir toward the Tajik basin (Metzger et al., 2020). The wedge-shaped Peter the First Range is squeezed between the dextral-transpressive Vakhsh and the sinistral-transpressive Darvaz faults, indicat- 
ing its NW-SE shortening and NE-SW lengthening (Kufner et al., 2018; Mohadjer et al., 2010). The Illiac and Darvaz fault zones are primarily strike-slip, but near the northwest of Pamir, where they become a parallel fault zone, they transform into an oblique thrusting zone (Kufner et al., 2018). The E-W extension is the result of norward movement and gravitational collapse as well as westward lateral extrusion of the Pamir crust into the Tajik basin, where lateral transported materials have thickened the crust of the Tajik Basin in the western causing NW-SE shortening of the $\sim 7-12 \mathrm{~km}$ thick sedimentary rocks (Kufner et al., 2018; Nikolaev, 2002; Rutte et al., 2017).

According to earthquake catalogues, crustal seismicity is most active along with the Pamir thrust system in the north and the Peter the First range in the northwest, both of which are mostly shallower than 12 kilometres (Kufner et al., 2018). Most seismicity in Peter the First Range occurs along with the northern and southern segments of the Darvaz fault (Kufner et al., 2018; Metzger et al., 2020). In comparison, the Tajik Depression is less seismically active, with the exception of a few sparse occurrences at the base and above the sedimentary layer within a depth of 40 kilometres, which are dominated by thrust earthquakes (Metzger et al., 2020). Strike slip mechanism dominates along the Darvaz, Ilyak and Vakhsh fault system, but farther to the northeast, it transforms to thrusting. Over the past 110 years, prominent earthquakes with a magnitude of +7 including the 1949 Khait earthquake, 1911/2015 Sarez earthquakes and the 1974 Markansu earthquake occurred along with the Darvaz and Vakhsh fault systems (Kufner et al., 2018; Metzger et al., 2017).

The Khait earthquake of 1949 is one of the strongest earthquakes, as a result of which large landslides and numerous landslides were formed (Gubin, 1960). The strength of the Khait earthquake, which captured the upper and middle reaches of the valley of the Surkhob River, reached 9 points on the Richter scale with a magnitude of 7.5. In the aftermath of the earthquake with great force, a huge number of earth avalanches with a volume of up to 300 million $\mathrm{m}^{3}$, several tens of meters thick, roared from the mountains. More than 20 settlements were affected. The landslide mass in the Yasman River valley formed a blockage about $20 \mathrm{~km}$ long and more than $1 \mathrm{~km}$ wide. Numerous cracks have formed in the slopes of the mountains and river terraces. During the Khait earthquake on an area of $1400 \mathrm{~km}^{2}$, about 1100 landslides of various types were recorded (Semenov \& Semenova, 1958).

The impact of landslide processes in the Surkhob river valley is rather uneven. These processes are widely developed in foothill zones. Zones of continuous development of landslides are observed in separate areas of the middle and upper reaches of the Surkhob River and its tributaries. The development of landslides concentrated in loess rocks is primarily characterized by the influence of climatic conditions and an increase in groundwater levels. Landslides in the loess rocks on the right and left sides of the Surkhob river valley are an example of this. In the formation of landslides in rocky and semi-rocky rocks, the influence of climatic factors and groundwater is minimal. 
Landslide bodies come in a variety of shapes, which are primarily determined by shifting rocks. Landslides in rocks have triangular, trapezoidal, or polygonal shapes and high shear walls. Frontal landslides are typical of semi-rocky rocks. Clayey and cohesive rocks are characterized by landslides that are circus-shaped, pear-shaped, or ellipsoidal in shape.

The primary goal of this research is to assess the intensity of development and predict the likelihood of landslides in the Surkhob River valley. A number of methods for mapping landslide susceptibility have been developed. We used the most common methods for the Surkhob River valley, such as the FR and AHP. The area's susceptibility to landslides was assessed using slope (degree), aspect of slope, curvature, stream power index, topographic wetness index, precipitation, and altitude. Finally, a unified landslide susceptibility map was created, which is divided into five categories (very high, high, medium, low and very low). ROC was used to estimate the quality of the landslide susceptibility map.

Landslide susceptibility mapping is essential for predicting the occurrence of likely future landslides and, as a first step, helps planners in deciding the impact of likely landslides (Majid et al., 2016). The quantity and quality of available data, the scale of the area studied, and the choice of methodology for analysis and modeling play an important role in the mapping of landslide susceptibility (Roodposhti et al., 2014).

\section{Study Area}

The Surkhob River (Figure 1), flowing from east to west, is the upper course of the Vakhsh River and is formed at the confluence of the Muksu and Kyzylsu rivers. The length of the Surkhob River from the mouth of the Muksu River to the mouth of the Obikhingou River is $145 \mathrm{~km}$. The width of the river bed of the Surkhob is changeable, in the extended parts of the valley it reaches $1 \mathrm{~km}$.

The valley of the Surkhob River is bounded in the north by the Karategin ridge, and in the south by the ridge of Peter the Great.

The formation of a large portion of modern active landslides and those in a state of temporary stability are observed within the Karategin ridge and the northern slopes of the Peter the Great ridge on the territory of the Surkhob River valley. The Karategin ridge, which is the largest spur of the Gissar ridge, stretches from the north-east to the south-west. The Peter the Great Ridge is characterized by an asymmetric structure, where the northern slope is short and the southern slope is gentle and long. A large number of landslides in this region are confined to structural-tectonic blocks, separated by zones of active faults.

\section{Modeling the Susceptibility to Landslides Using the Frequency Ratio Method}

When assessing the hazard of landslides, much attention is paid to the detailed determination of the temporary occurrence of landslides (Paolo et al., 2008), which is a difficult task. The assessment of susceptibility to landslides, which 


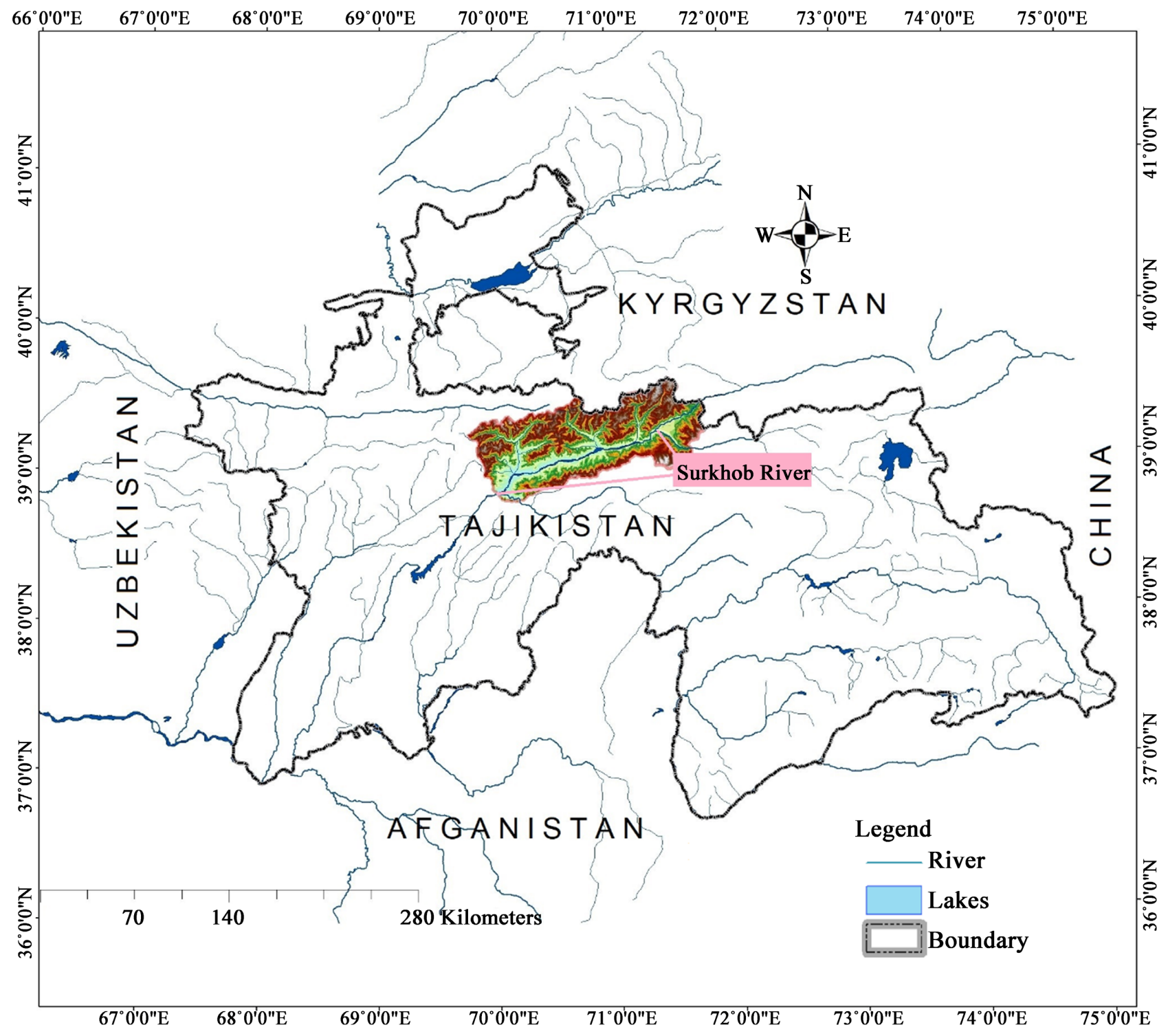

Figure 1. Location map of the study area.

determines the territory's tendency to the occurrence of landslides or the likelihood of their spatial occurrence on slopes, is of great practical interest in assessing the hazard of landslide processes of a local and regional nature (Guzzetti et al., 2005; Guzzetti et al., 2006).

The landslide susceptibility map is compiled for those regions where landslide processes are widespread (Santacana et al., 2003) and places with the future development of landslides. Factor-based mapping highlights potentially unstable slopes (Ayalew et al., 2005). It will bring together a number of critical factors that contributed to landslides occurring. The proclivity of soil or rock to produce various types of landslides is referred to as landslide susceptibility (Christos et al., 2014). The landslide susceptibility map is used to select the most suitable locations for the construction of structures and communication lines. The reliability of the landslide susceptibility maps is based on the quantity and quality of the 
data obtained and the choice of appropriate interpretation and modeling methods (Ayalew \& Yamagishi, 2005). The creation of such maps is based on qualitative or quantitative methods of analysis (Soeters \& Westen, 1996; Aleotti \& Chowdhury, 1999; Guzzetti et al., 1999). Local and regional data is used extensively in the creation of susceptibility maps. Using geographic information systems (GIS) to map susceptibility and update the receptivity assessment process is a beneficial tool (Ayalew et al., 2005).

\section{Materials and Methods}

\subsection{Landslide Inventory}

To study the spatial relationship of distribution and establish the factors of landslide conditioning, it is important to prepare a landslide inventory map (Zhuo et al., 2020), where landslide locations, outlines and characteristics are applied. A landslide distribution map of the Surkhob River valley, for spatial data assessment, was compiled on the basis of Google Earth imagery, shuttle radar topography mission (SRTM), digital elevation model (DEM), geological maps at a scale of 1:200,000 and a map of the distribution of glacial forms of mudflow and gravity phenomena on the territory of Tajikistan at a scale of 1:500,000. For the reliability of the landslide inventory of the study area, field studies (Figures 2-4(a)) were carried out using GPS and interpretation of aerial and satellite images.

\subsection{Landslide Conditioning Factors}

The first step in mapping landslide susceptibility was to identify the conditioning factors that define the development of landslides. In this study, seven factors were considered in determining the likelihood of landslides: slope (degree), curvature, altitude, TWI, SPI, slope aspect, and precipitation.

\subsubsection{Slope (Degree)}

The slope angle is one of the most important factors in the analysis of slope instability, and it is directly related to landslides (Yalcin, 2008). This factor has a direct relationship with shear stresses, which affect slope displacement. In local studies, the angle of inclination influences moisture concentration and pore pressure (Ayalew \& Yamagishi, 2005), and for large-scale regional hydraulic continuity (Guzzetti et al., 1999). To analyze the data from the study area, seven slope map classes were chosen: 0 - 50, 50 - 100, 100 - 200, 200 - 300, 300 - 400, 400 - 500 and $>500$ (Figure $4(\mathrm{~b})$ ).

\subsubsection{Curvature}

The morphology of the topography is established by the curvature (Pourghasemi et al., 2013). Curvature controls surface runoff and influences the occurrence of landslides (Dou et al., 2019). Curvature was compiled using DEM and divided into three classes (Figure $4(c)$ ): convex (>0.01), flat $(-0.1$ to 0.01$)$, and concave $(<-0.1)$. 
(a)

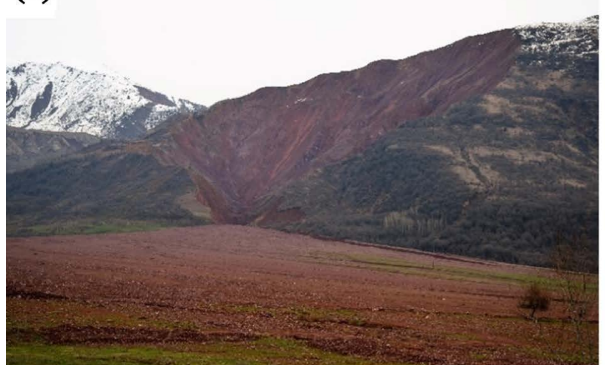

(c)

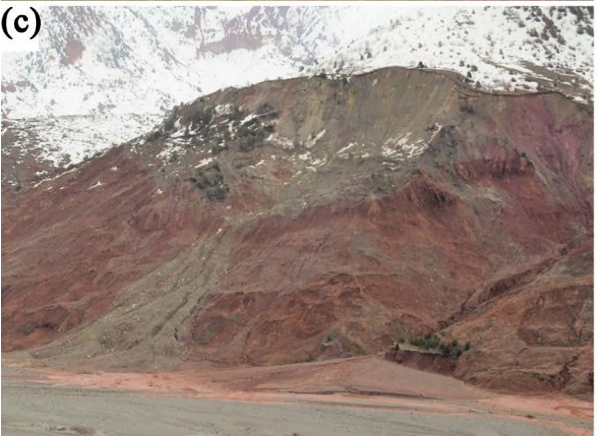

(e)

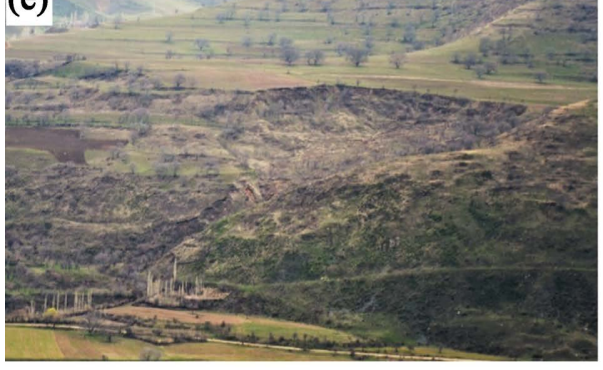

(b)

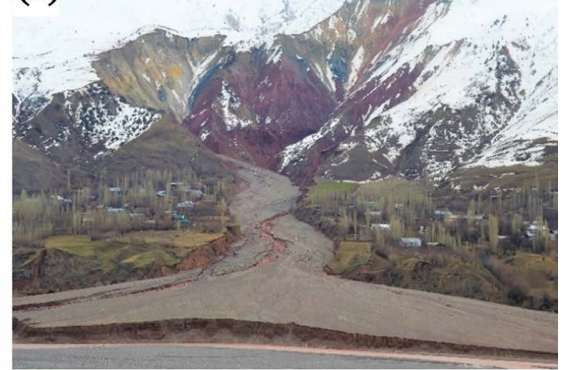

(d)

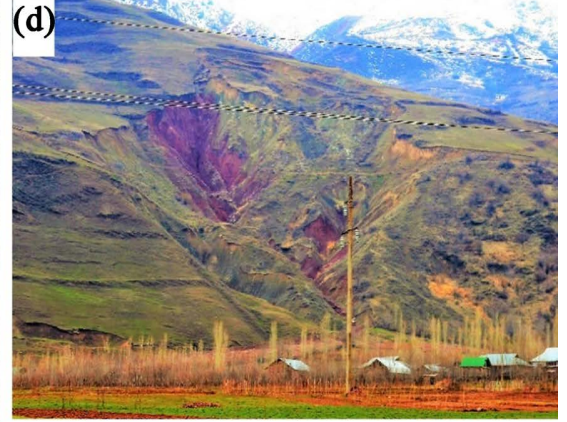

(f)

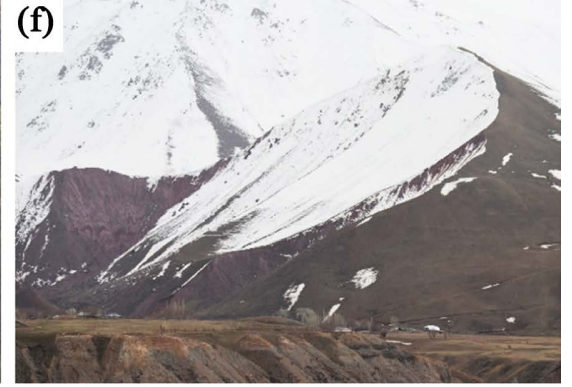

Figure 2. Landslides in Cretaceous sediments on the left side of the Surkhob River (Northern slope of the Peter the Great Ridge). (a)-(f): Circus landslides; (d) Teardropshaped landslide.
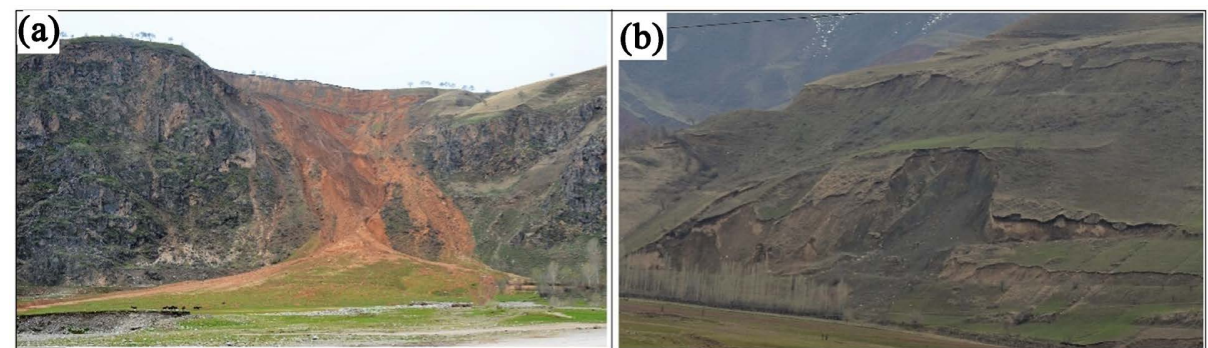

(c)

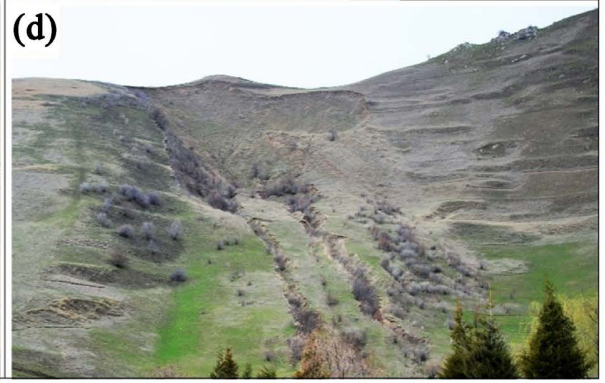

Figure 3. Development of landslides in the loess of the right side of the Surkhob River (Karategin ridge). (a) and (d): Stream; (b) and (c): Circus landslide. 

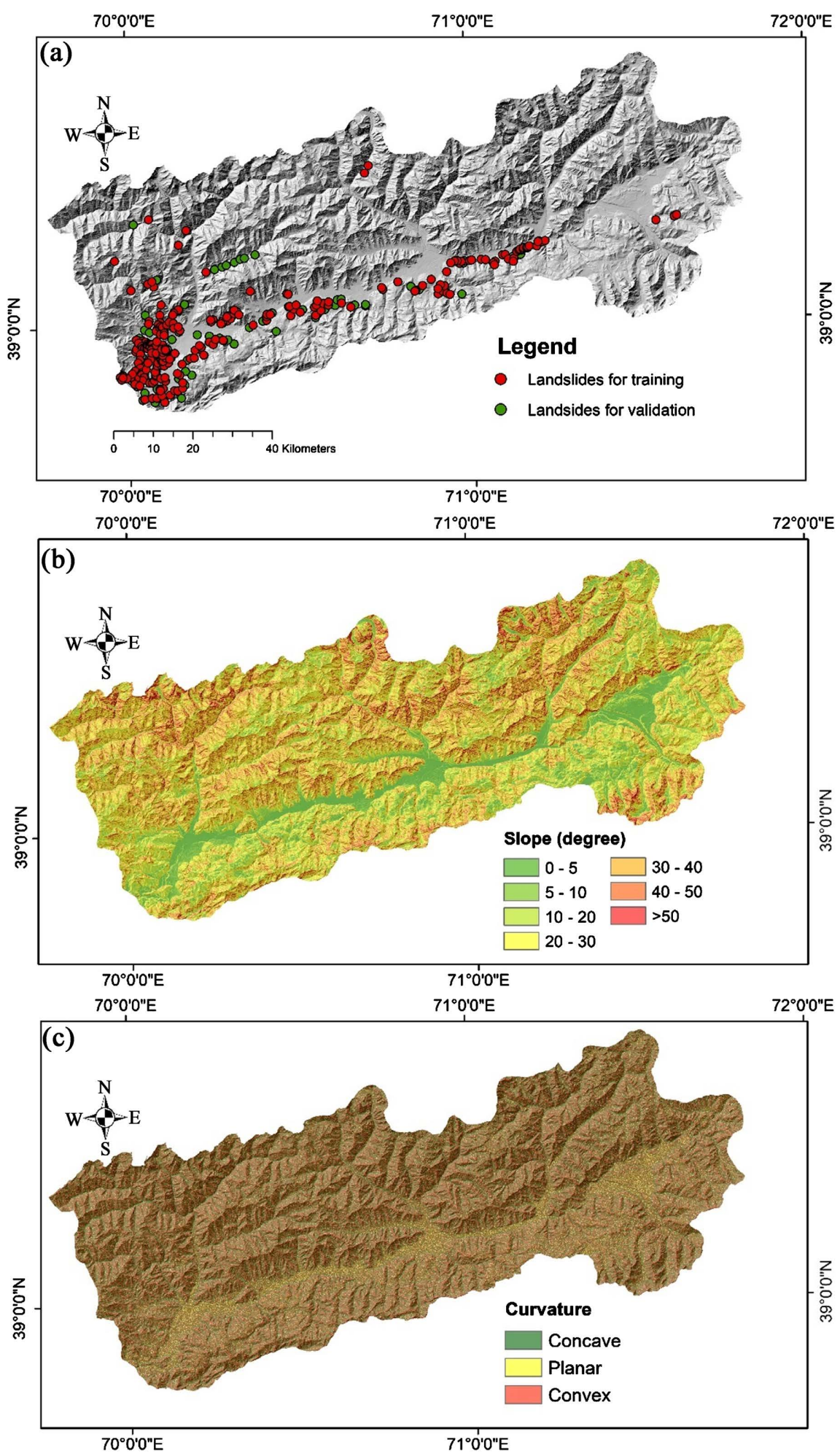

Figure 4. Maps of landslide conditioning factors: (a) Maps of landslide inventory; (b) Slope (degree); (c) Curvature.

\subsubsection{Altitude}

When analyzing landslides, height is an important component. This factor is used to classify the local relief and determine the maximum and minimum 
height within the study area (Ayalew \& Yamagishi, 2005). It is primarily associated with the geological, geomorphological and tectonic conditions of the territory. When compiling a height map, seven classes were selected: $1143-2000$ m, 2000 - 2500 m, $2500-3000$ m, $3000-3500$ m, $3500-4000$ m, $4000-4500$ m and $4500-5922 \mathrm{~m}$ (Figure 5(a)).
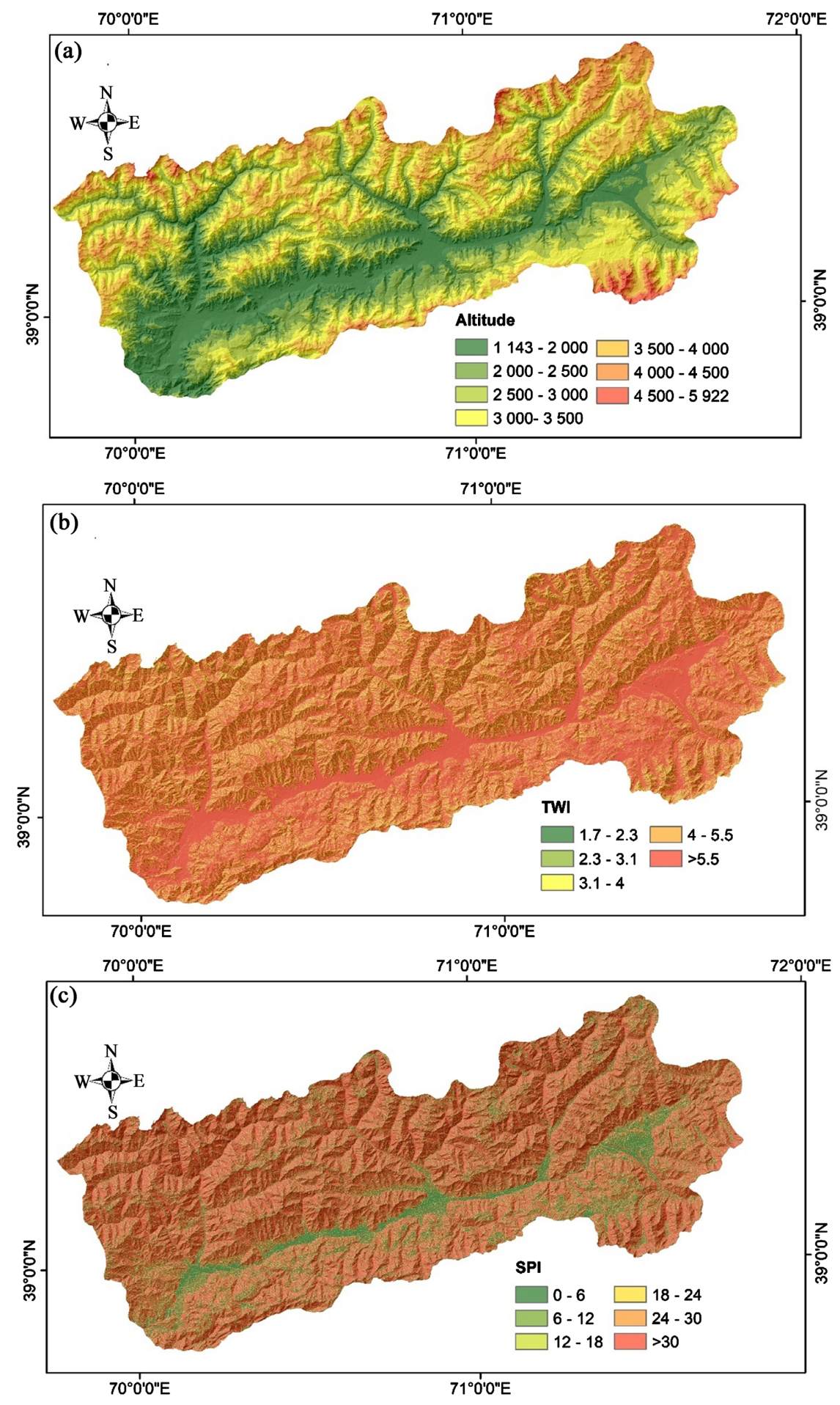

Figure 5. Landslide conditioning factor maps: (a) Altitude; (b) TWI; (c) SPI. 


\subsubsection{Topographic Wetness Index (TWI)}

This factor determines the topography, location and size of saturated runoff sources (Pourghasemi et al., 2013; Pradhan \& Kim, 2014) and affect the stability of slopes and the occurrence of landslides. It was found that with an increase in TWI, the susceptibility to landslides increases (Viet-Ha et al., 2020). TWI describes the saturation potential of a given section in relation to the area of rise and local slope (Beven \& Kirkby, 1979; Barbosa et al., 2021).

$$
T W I=\ln \left(\frac{a}{\tan b}\right)
$$

where $a$ is the local area of uplift that flows down through a specific point, $b$ is the local slope in radians. High TWI values indicate flat areas with large uplift areas that have relatively high-water availability, while low values correspond to steep areas that are better drained (Sørensen \& Sorensen, 2007; Barbosa et al, 2021). The TWI card is divided into 5 classes: $1.7-2.3 ; 2.3-3.1 ; 3.1-4 ; 4-5.5$ and $>5.5$ (Figure $5(\mathrm{~b})$ ).

\subsubsection{Stream Power Index (SPI)}

This factor is a measure of the erosional capacity of the flow, contributing to the stability of slopes in the study area (Conforti et al., 2011; Regmi et al., 2014; Trigila et al., 2015). The SPI map of the Surkhob river valley is divided into six classes: 0 - 6, 6 - 12, $12-18,18-24,24-30,>30$ (Figure 5(c)).

\subsubsection{Aspect of Slopes}

This factor determines the direction of the slope, where it primarily indirectly affects its stability. Monitors changes in slope morphology and hydrology. Due to the different humidity, it affects the occurrence of landslides (Ebrahim et al., 2019), hydrogeological processes (Sadr et al., 2014) and soil moisture (Sidle \& Ochiai, 2006). Slope aspect information is taken from the DEM and divided into nine categories (Figure 6(a)): plain, north, northeast, east, southeast, south, southwest, west, and northwest.

\subsubsection{Precipitation}

Precipitation is one of the main parameters when mapping landslide susceptibility (Wang et al., 2015). The frequency of landslides is positively correlated with the quantity and intensity of precipitation, and their relationship is more dependent on topography (Viet-Ha et al., 2020), they on relatively flat terrain may have less impact on slope stability than in hilly areas (Yilmaz, 2009). Rainfall information for this study area was taken from the global climate site and classified into seven classes 338 - 500, 500 - 600, 600 - 700, 700 - 800, 800 - 900, 900 - 1000, and $1000-1190$ (Figure 6(b)).

\subsection{Methodology}

The study was conducted on the basis of an integrated weighted index model through three stages: 1) Determining the relative importance of landslide management factors using the analytical hierarchical process (AHP) method; 2) 

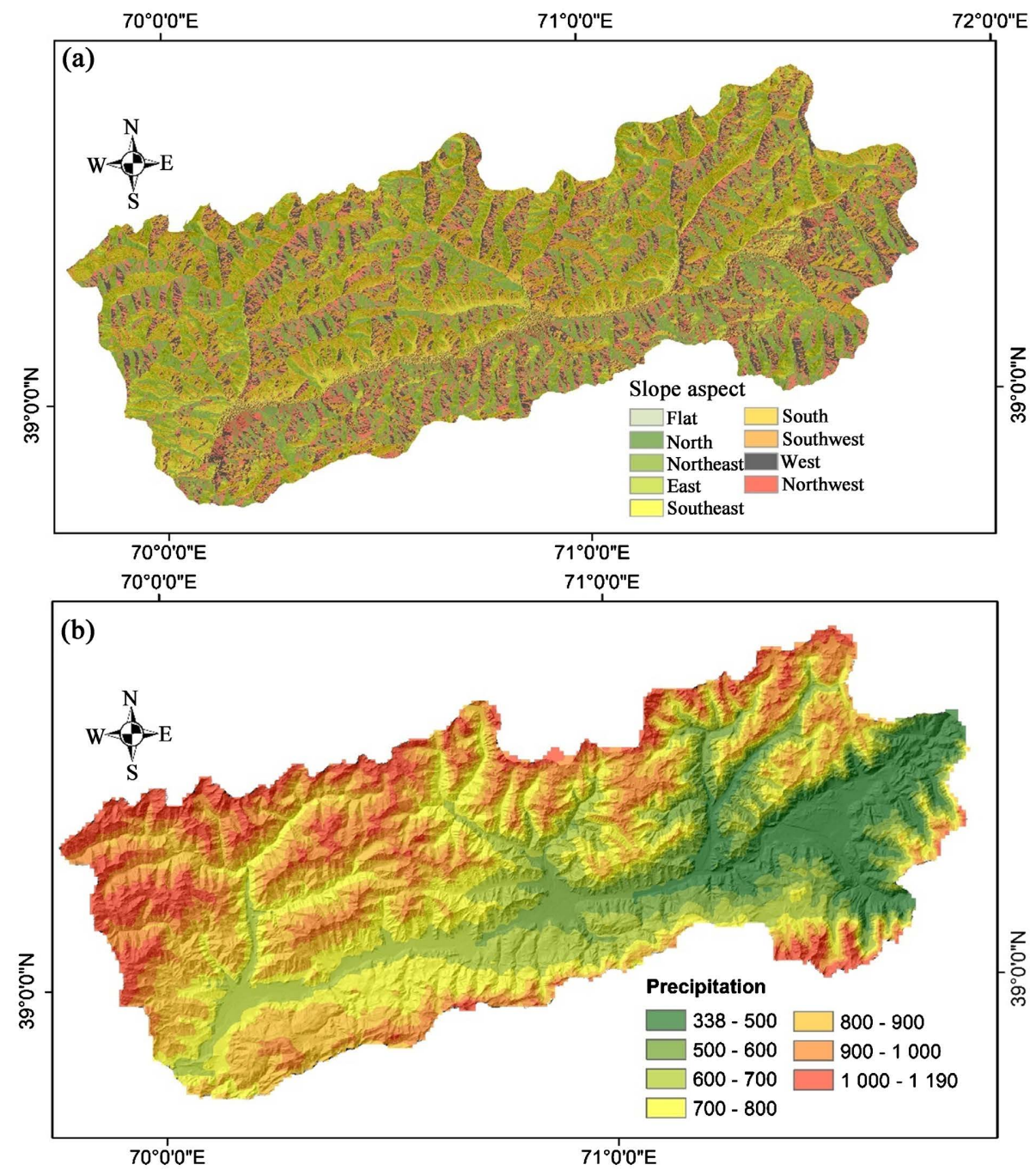

Figure 6. Landslide conditioning factor maps: (a) slop aspect and (b) precipitation.

Characterizing the relationships between control factors and landslide locations using frequency ratio (FR) and GIS techniques and 3) predicting susceptibility to landslides using the ArcGIS Weighted Overlay Analysis tool (Yi et al., 2019). By combining the Analytical Hierarchical Process (AHP) and Frequency Relationship (FR), a complete landslide susceptibility model is constructed.

\subsubsection{Analytical Hierarchy Method (AHP)}

According to this method (Saaty, 1977), decisions are made according to several criteria (Vaidya \& Kumar, 2006), where the AHR is divided into several constituent factors, and based on the importance of each factor, a pairwise comparison matrix can be constructed (Vargas, 1990). A nine-point registration scale is used to assess the importance of factors (Daneshvar, 2014), where the score varies when one factor is more important than another 1 to 9 and vice versa from $1 / 2$ to $1 / 9$ (Yi et al., 2019). Based on the assessment results, it can be determined that the higher the assessment, the greater the importance of the factor over other factors. 


\subsubsection{Frequency Ratio (FR) Method}

This method is widely used to assess the susceptibility to landslides on a regional scale (Yi et al., 2019; Guo et al., 2015; Li et al., 2017; Mohammady et al., 2012). The FR method was developed based on the observed spatial relationship between landslide location and control factors (Lee \& Pradhan, 2007). The basis of the FR method is that new landslides will occur under the same conditions as historical landslides (Guzzetti et al., 1999), and the susceptibility is assessed by the relationship between control factors and landslide occurrence locations (Zhu et al., 2014; Yi et al., 2019). In addition, the FR method investigates the spatial relationship between landslides and control factors. The mean FR is found to be 1 , so a value greater than 1 represents a higher correlation, and less than 1 a lower correlation (Romer \& Ferentinou, 2016).

The FR value is calculated using this formula (Ghobadi et al., 2017):

$$
F R_{i}=\frac{\operatorname{Ncell}\left(S_{i}\right) / \operatorname{Ncell}\left(N_{i}\right)}{\sum \operatorname{Ncell}\left(S_{i}\right) / \sum \operatorname{Ncell}\left(N_{i}\right)},
$$

where Ncell $\left(S_{i}\right)$ is the number of grid cells recognized as landslides in class $i$, Ncell $\left(N_{i}\right)$ is the total number of grid cells belonging to class $i$ in the entire area. $\Sigma$ Ncell $\left(S_{i}\right)$ the total number of grid cells recognized as landslides in the entire area and $\Sigma$ Ncell $\left(N_{i}\right)$ the total number of grid cells in the entire area.

The summarized results of the effects of each class of factors that were determined using the frequency ratio equation method are shown in Table 2.

\section{Results and Discussion}

\subsection{Analytical Hierarchy Method (AHP)}

AHP is used in the assessment of landslide susceptibility to identify factors influencing landslide formation. When calculating their weight, this method is used to determine the relative importance of all factors and classes that influence landslide susceptibility. When creating a hierarchy of decision-making criteria, each factor is compared to each other in a pairwise matrix assessment. Each factor in the matrix is scored differently in the matrix based on comparative priority affecting landslides (Saaty, 1977). The criterion is assessed according to the paired comparison scale). The more significant coefficient on the matrix's vertical axis in relation to the sign of the horizontal axis, the value differs from 1 to 9 , and if the difference between reciprocal values is from $1 / 2$ to $1 / 9$. To calculate the average weight of each factor, the columns are first adjusted by dividing the members of each column by the total of the column. The elements in each resulting line are then added up and divided by the number of elements in the line.

Table 1 shows a matrix of pairwise comparison of all studied factors. The weights for the nine governing factors of the Surkhob river valley are estimated as follows (Table 2): TWI-0.03, SPI-0.05, height-0.07, curvature-0.10, aspect- 0.15 , precipitation- 0.22 and slope- 0.38 . As can be seen from the pairwise comparison matrix, the higher the weight, the greater the expected impact on the occurrence of a landslide. The highest isslope and precipitation, which 
Table 1. The pair-wise comparison matrix, factor weights, and consistency ratio

\begin{tabular}{ccccccccc}
\hline Item Description & TWI & SPI & Elevation & Curvature & Aspect & Precipitation & Slope & Weight \\
\hline TWI & 1.00 & 0.50 & 0.33 & 0.25 & 0.20 & 0.17 & 0.14 & 0.03 \\
SPI & 2.00 & 1.00 & 0.50 & 0.33 & 0.25 & 0.20 & 0.17 & 0.05 \\
Elevation & 3.00 & 2.00 & 1.00 & 0.50 & 0.33 & 0.25 & 0.20 & 0.07 \\
Curvature & 4.00 & 3.00 & 2.00 & 1.00 & 0.50 & 0.33 & 0.25 & 0.10 \\
Aspect & 5.00 & 4.00 & 3.00 & 2.00 & 1.00 & 0.50 & 0.25 & 0.15 \\
Precipitation & 6.00 & 5.00 & 4.00 & 3.00 & 2.00 & 1.00 & 0.33 & 0.22 \\
Slope & 7.00 & 6.00 & 5.00 & 4.00 & 4.00 & 3.00 & 1.00 & 0.38 \\
\hline
\end{tabular}

means most of their influence are on the occurrence of landslides. The lowest rates are TWI and SPI, this indicates the least role of these factors in the occurrence of landslides.

\subsection{Frequency Ratio (FR)}

To determine the occurrence of landslides in the Surkhob River valley, the weight value of the classes of landslide factors was calculated using frequency ratio methods (Table 2). For all classes of factors, the frequency coefficient was nominal, where the influence of each class of landslide factors on slope instability was established. As seen in Table 2 for classes tilt angle $0-5,5-10,10-20$ and $>50$ a low FR value is characteristic $(0.11,0.43,0.96$ and 0.50 , respectively) and for the slope angle classes 20 - 30, 30 - 40, 40 - 50, a high FR value is characteristic (1.23 and 1.01 respectively).Based on this correlation, it was found that the likelihood of landslides increases as the angle of inclination increases. However, at an angle of inclination $>50$, the opposite is observed, the likelihood of landslides fits. In the class of aspect factors for the flat (0.02), southern (0.88), southwestern (0.54) and western (0.87) sides, the FR value is $<1$, which indicates a low probability of landslides. The rest of the aspect classes, northern, northeastern, eastern, southeastern and northwestern, have FR $>1$, which indicates a high probability of landslides. So, it can be seen from Table 2 the value of the FR of the height class for $1143-2000 \mathrm{~m}$ and $2000-2500 \mathrm{~m}$ is characterized by a high FR value (2.87 and 1.71, respectively), which indicates a high probability of landslides, and for the remaining classes, a low FR value is set. This correlation indicates that the likelihood of landslides decreases with increasing altitude. A high value of the FR of the slope curvature class is characteristic of concave (1.02) slopes, indicating a high probability of landslides. The inverse relationship is typical for flat slopes, where the FR value is low (0.92). On convex slopes near the average value of FR of the curvature class is established, where it is equal to 1. A high value of FR of precipitation in the study area is established for classes $600-700,700-800$ and $800-900$, which indicates a high probability of landslides. For classes $338-500,500-600,900-1000$ and $1000-1190$, the FR indicator of precipitation is low $(0.37 ; 0.64,0.35$ and 0.07 , respectively). With the 
Table 2. Spatial relationship between each landslide factors and landslide using frequency ratio.

\begin{tabular}{|c|c|c|c|c|c|c|}
\hline Factors & Class & Ncell (Ni) & $\Sigma$ Ncell (Ni) & Ncell (Si) & $\sum$ Ncell (Si) & FRi \\
\hline \multirow[t]{7}{*}{ Slope (Degree) } & $0-5$ & 698,275 & & 693 & & 0.11 \\
\hline & $5-10$ & 855,927 & & 3261 & & 0.43 \\
\hline & $10-20$ & $2,191,745$ & $10,902,214$ & 18,747 & 97,013 & 0.96 \\
\hline & $20-30$ & $2,989,718$ & & 32,738 & & 1.23 \\
\hline & $30-40$ & $2,754,838$ & & 30,104 & & 1.23 \\
\hline & $40-50$ & $1,147,180$ & & 10,297 & & 1.01 \\
\hline & $>50$ & 264,531 & & 1173 & & 0.50 \\
\hline \multirow[t]{9}{*}{ Aspect } & Flat & 10,741 & & 2 & & 0.02 \\
\hline & North & $1,443,722$ & & 18,691 & & 1.45 \\
\hline & Northeast & $1,238,752$ & $10,902,214$ & 11,230 & 97,013 & 1.02 \\
\hline & East & $1,287,487$ & & 11,657 & & 1.02 \\
\hline & Southeast & $1,381,378$ & & 12,749 & & 1.04 \\
\hline & South & $1,390,242$ & & 10,920 & & 0.88 \\
\hline & Southwest & $1,260,106$ & & 6052 & & 0.54 \\
\hline & West & $1,432,711$ & & 11,082 & & 0.87 \\
\hline & Northwest & $1,457,075$ & & 14,630 & & 1.13 \\
\hline \multirow[t]{7}{*}{ Altitude } & $1143-2000$ & $1,890,315$ & & 48,260 & & 2.87 \\
\hline & $2000-2500$ & $1,908,386$ & & 29,009 & & 1.71 \\
\hline & $2500-3000$ & $2,084,264$ & $10,902,214$ & 15,361 & 97,013 & 0.83 \\
\hline & $3000-3500$ & $2,300,951$ & & 3560 & & 0.17 \\
\hline & $3500-4000$ & $2,004,771$ & & 753 & & 0.04 \\
\hline & $4000-4500$ & 599,657 & & 70 & & 0.01 \\
\hline & $4500-5922$ & 113,870 & & 0 & & 0.00 \\
\hline \multirow[t]{3}{*}{ Curvature } & Concave & $5,127,677$ & & 46,429 & & 1.02 \\
\hline & Planar & 887,690 & $10,902,213$ & 7293 & 97,013 & 0.92 \\
\hline & Convex & $4,886,846$ & & 43,291 & & 1.00 \\
\hline \multirow{7}{*}{$\begin{array}{c}\text { Precipitation } \\
\text { (mm/years) }\end{array}$} & $338-500$ & $1,097,300$ & & 3648 & & 0.37 \\
\hline & $500-600$ & 983,972 & & 5602 & & 0.64 \\
\hline & $600-700$ & $1,600,635$ & $10,823,104$ & 15,661 & 96,308 & 1.10 \\
\hline & $700-800$ & $1,932,117$ & & 27,033 & & 1.57 \\
\hline & $800-900$ & $2,420,998$ & & 38,813 & & 1.80 \\
\hline & $900-1000$ & $1,765,628$ & & 5551 & & 0.35 \\
\hline & $1000-1190$ & $1,022,454$ & & 647 & & 0.07 \\
\hline
\end{tabular}




\begin{tabular}{|c|c|c|c|c|c|c|}
\hline \multicolumn{7}{|l|}{ Continued } \\
\hline \multirow[t]{5}{*}{ TWI } & $1.7-2.3$ & 199 & & 0 & & 0.00 \\
\hline & $2.3-3.1$ & 17,898 & & 62 & & 0.39 \\
\hline & $3.1-4$ & 656,171 & $10,902,214$ & 5627 & 96,951 & 0.96 \\
\hline & $4-5.5$ & $4,220,421$ & & 40,763 & & 1.09 \\
\hline & $>5.5$ & $6,007,525$ & & 50,561 & & 0.95 \\
\hline \multirow[t]{6}{*}{ SPI } & $0-6$ & $2,424,750$ & & 16,304 & & 0.76 \\
\hline & $6-12$ & 457,849 & & 2679 & & 0.66 \\
\hline & $12-18$ & 568,546 & $10,902,214$ & 4660 & 97,013 & 0.92 \\
\hline & $18-24$ & 546,554 & & 4960 & & 1.02 \\
\hline & $24-30$ & 437,499 & & 3944 & & 1.01 \\
\hline & $>30$ & $6,467,016$ & & 64,466 & & 1.12 \\
\hline
\end{tabular}

correlation of the class of precipitation factors, it was found that the probability of landslides has a stepwise character, low-high-low. The study of the factors, the index of topographic humidity showed that the lowest FR values are characteristic for the classes 1.7 - $2.3(0.0), 2.3$ - 3.1 (0.39), 3.1 - 4 (0.96) and $>5.5$ (0.95), which indicates a low probability of landslides. Only one grade $4-5.5$ had a high FR score (1.09). Correlation of the data showed that using the index of the class SPI increases the values of FR.

\subsection{Landslide Susceptibility Mapping}

The landslide susceptibility map of the Surkhob River valley was created using the Weighted Overlay analysis tool of ArcGIS. As shown in Figure 7, the study area is divided into five categories of landslide susceptibility levels: very high, high, medium, low and very low.

As shown in the landslide susceptibility map, areas with high and very high susceptibility are located close to rivers and in the middle of the highlands, these are mainly left and right sides of the middle and lower part of the Surkhob River. Of the total area of the study area, the zone with very low susceptibility covered $20 \%$, with low- $21 \%$, medium- $20 \%$, high- $26 \%$ and very high- $13 \%$.

\subsection{Model Validation}

The final step in mapping susceptibility to landslides, which can be used to assess the accuracy of the model, is model validation. There are various methods for validating a model -success and predictive rate curve, landslide relative density index (R-index), receiver operating characteristic curve (ROC) and area under the curve (AUC) (Azemeraw, 2021). In this paper, the accuracy of the landslide susceptibility model was evaluated using the frequency ratio method.

As the results of the analysis in Figure 8 show, the AUC value for FR is 0.877 of the predicted indicators and the success curve. This indicator is a good 


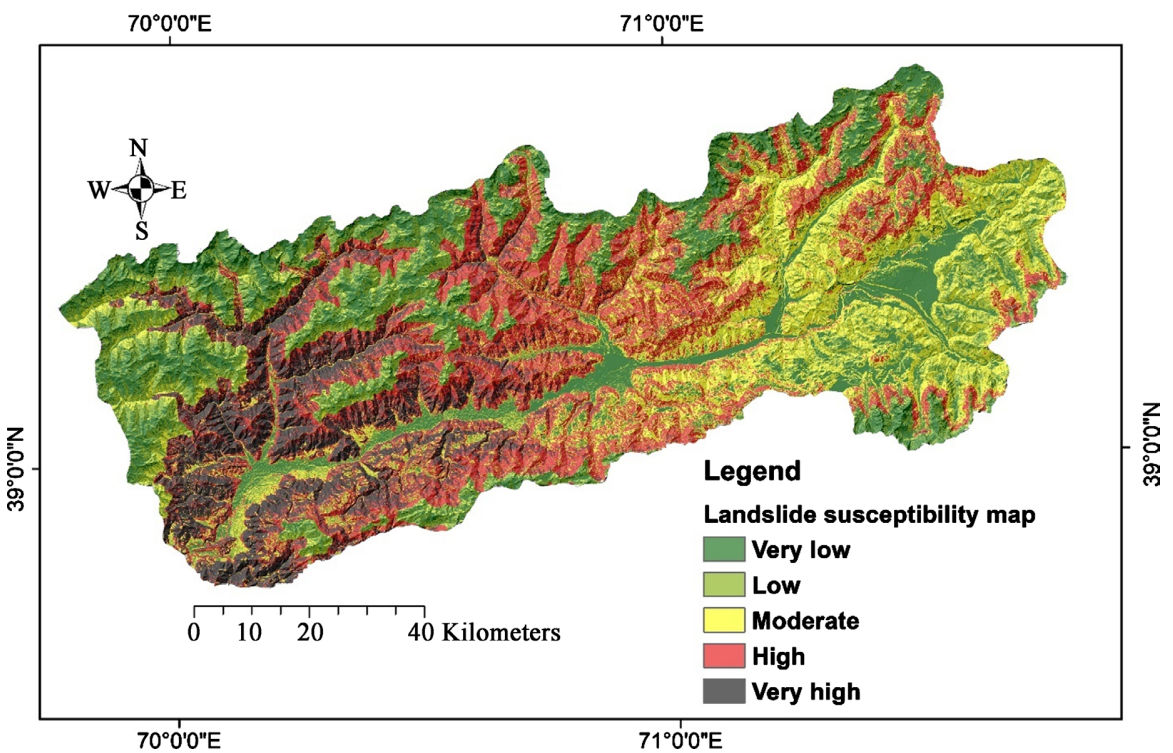

Figure 7. Landslide susceptibility maps produced by FR.

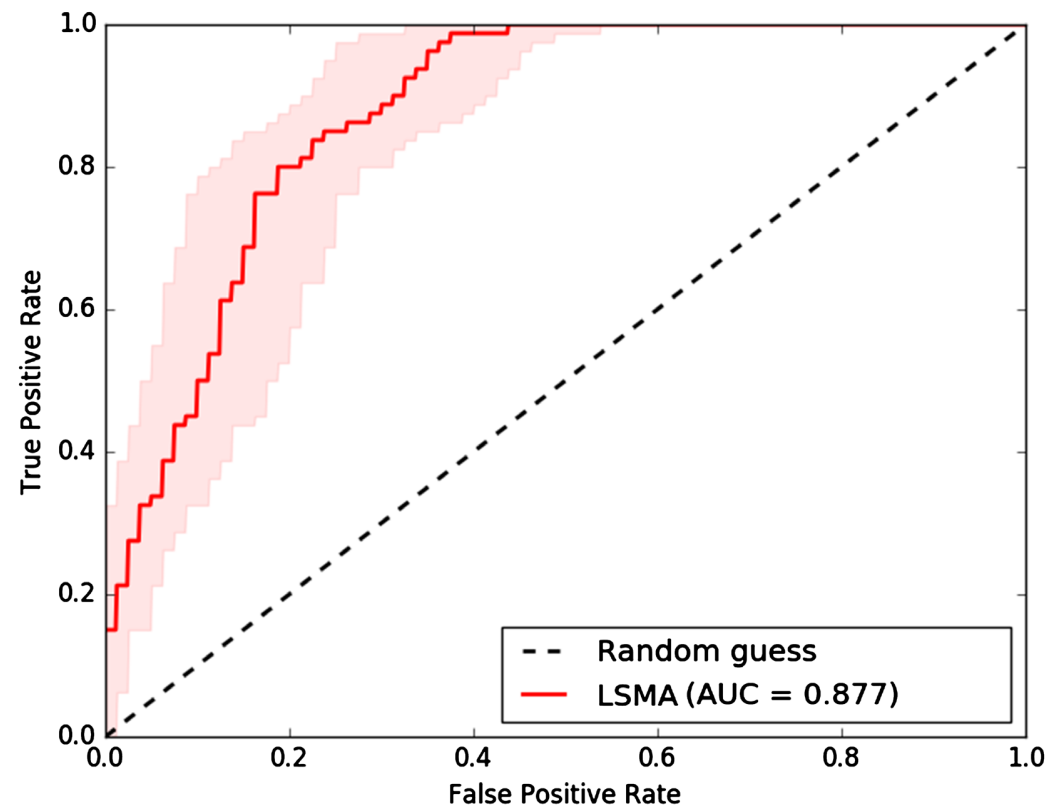

Figure 8. Receiver operating characteristics curve (ROC).

agreement between the occurrence of landslides and the mapped area susceptibility.

\section{Conclusion}

According to recent research, landslide susceptibility modelling is an effective strategy for reducing the negative impact of landslides on the environment. This type of work allows us to forecast landslides in high-risk areas. The FR and AHP methods were used to create a landslide susceptibility map for the Surkhob river basin. A total of 416 landslide locations were determined using remote sensing, mapped in a landslide inventory map, and confirmed through fieldwork. The 
locations were categorized into two main datasets for training (336) and validation (80). Seven causative factors (slope, slope aspect, curvature, precipitation, altitude, TWI and SPI) were taken into account for accomplishing model.

The landslide susceptibility map divided the study area into five zones: very high, high, moderate, low and very low (Based on the sum of all weighted factors). The landslide susceptibility map shows that almost all of the landslides in the study area that was used for validation are susceptible to landslides (69\%) were grouped in high (35\%) very high and (64\%) susceptibility zones which confirms the high accuracy of our model.

The main findings of this study are derived from the information provided by the analysis and statistics results of the calculation of weights performed via the correlation between the landslide inventory map and the causative factors (Table 2) and the susceptibility map (Figure 7). They show that landslides form on slopes of $20-30$ and $30-40$ degrees with north, northeast, and northwest orientations at an altitude of 1143 - 2000 meters.

Furthermore, the probability of a landslide occurring is highest in TWI at 4 5, 5 and $>5.5$ measures, and the probability of a landslide occurring increases with increasing SPI measures. Another factor that has a direct influence on landslide occurrence is mean annual precipitation, and most landslides in the Surkhob river basin are associated with 700 - 800 and 800 - 900 measures. Curvature is the final factor used for landslide susceptibility mapping, and almost all classes assigned equal weight to it.

The ROC curve was used to assess the accuracy of the landslide susceptibility model. The AUC prediction rate curve value for our model is 0.877 , indicating that the model is very accurate.

The resulting susceptibility map provides information on existing and future landslides to land planners and engineers in order to establish in advance the hazard caused by landslides.

\section{Conflicts of Interest}

The authors declare no conflicts of interest regarding the publication of this paper.

\section{References}

Aleotti, P., \& Chowdhury, R. (1999). Landslide Hazard Assessment: Summary Review and New Perspectives. Bulletin of Engineering Geology and the Environment, 58, 21-44. https://doi.org/10.1007/s100640050066

Ayalew, L., \& Yamagishi, H. (2005). The Application of GIS-Based Logistic Regression for Landslide Susceptibility Mapping in the Kakuda-Yahiko Mountains, Central Japan. Geomorphology, 65, 15-31. https://doi.org/10.1016/j.geomorph.2004.06.010

Ayalew, L., Yamagishi, H., Marui, H., \& Kanno, T. (2005). Landslides in Sado Island of Japan: Part II. GIS-Based Susceptibility Mapping with Comparison of Results from Two Method Sand Verifications. Engineering Geology, 81, 432-445.

https://doi.org/10.1016/j.enggeo.2005.08.004 
Azemeraw, W. (2021). Landslide Susceptibility Mapping Using Statistical Methods in Uatzau Catchment Area, Northwestern Ethiopia. Geoenvironmental Disasters, 8, Article No. 1. https://doi.org/10.1186/s40677-020-00170-y

Barbosa, N., Andreani, L., Gloaguen, R., \& Ratschbacher, L. (2021). Window-Based Morphometric Indices as Predictive Variables for Landslide Susceptibility Models. Remote Sensing, 13, Article No. 451. https://doi.org/10.3390/rs13030451

Beven, K. J., \& Kirkby, M. J. (1979). A Physically Based, Variable Contributing Area Model of Basin Hydrology/Un modèle à basephysique de zone d'appel variable de l'hydrologie du bassin versant. Hydrological Sciences Journal, 24, 43-69. https://doi.org/10.1080/02626667909491834

Burtman, V. S., \& Molnar, P. (1993). Geological and Geophysical Evidence for Deep Subduction of Continental Crust Be Neath the Pamir. Geological Society of America, 281, 1-76. https://doi.org/10.1130/SPE281-p1

Carrapa, B., DeCelles, P. G., Wang, X., Clementz, M. T., Mancin, N., Stoica, M., Kraatz, B., Meng, J., Abdulov, S., \& Chen, F. (2015). Tectono-Climatic Implications of Eocene Paratethys Regression in the Tajik Basin of Central Asia. Earth and Planetary Science Letters, 424, 168-178. https://doi.org/10.1016/j.epsl.2015.05.034

Chapman, J. B., Carrapa, B., Ballato, P., DeCelles, P. G., Worthington, J., Oimahmadov, I., Gadoev, M., \& Ketcham, R. (2017). Intracontinental Subduction beneath the Pamir Mountains: Constraints from Thermokinematic Modeling of Shortening in the Tajik Fold-and-Thrust Belt. GSA Bulletin, 129, 1450-1471. https://doi.org/10.1130/B31730.1

Chen, Z., Ye, F., Fu, W. X., Ke, Y. T., \& Hong, H. Y. (2020). The Influence of DEM Spatial Resolution on Landslide Susceptibility Mapping in the Baxie River Basin, NW China. Natural Hazards, 101, 853-877. https://doi.org/10.1007/s11069-020-03899-9

Christos, C., Maria, F., \& Christos, P. (2014). GIS-Based Landslide Susceptibility Mapping on the Peloponnese Peninsula, Greece.Geosciences, 4, 176-190.

https://doi.org/10.3390/geosciences4030176

Conforti, M., Aucelli, P. P., Robustelli, G., \& Scarciglia, F. (2011). Geomorphology and GIS Analysis for Mapping Gully Erosion Susceptibility in the Turbolo Stream Catchment (Northern Calabria, Italy). Natural Hazards, 56, 881-898.

https://doi.org/10.1007/s11069-010-9598-2

Daneshvar, M. R. M. (2014). Landslide Susceptibility Zonation Using Analytical Hierarchy Process and GIS for the Bojnurd Region, Northeast of Iran. Landslides, 11, 1079-1091. https://doi.org/10.1007/s10346-013-0458-5

Dou, J., Yunus, A. P., Bui, D. T., Merghadi, A., Sahana, M., Zhu, Z., Chen, C. W., Khosravi, K., Yang, Y., \& Pham, B. T. (2019). Assessment of Advanced Random Forest and Decision Tree Algorithms for Modeling Rainfall-Induced Landslide Susceptibility in the Izu-Oshima Volcanic Island, Japan. Science of the Total Environment, 662, 332-346.

https://doi.org/10.1016/j.scitotenv.2019.01.221

Ebrahim, N., Meisam, M., Samira, S., Khabat, K, Biswajeet, P., Binh, T., Saro, L., \& Assefa, M. M. (2019). Landslide Susceptibility Mapping Using Different GIS-Based Bivariate Models. Water, 11, Article No. 1402. https://doi.org/10.3390/w11071402

Evans, S. G., Roberts, N. J., Ischuk, A., Delaney, K. B., Morozova, G. S., \& Tutubalina, O. (2009). Landslides Triggered by the 1949 Khait Earthquake, Tajikistan, and Associated Loss of Life. Engineering Geology, 109, 195-212.

https://doi.org/10.1016/j.enggeo.2009.08.007

Ghobadi, M. H., Nouri, M., Saedi, B., Jalali, S. H., \& Pirouzinajad, N. (2017). The Performance Evaluation of Information Value, Density Area, LNRF, and Frequency Ratio Methods for Landslide Zonation at Miandarband Area, Kermanshah Province, Iran. 
Arabian Journal of Geosciences, 10, Article No. 430. https://doi.org/10.1007/s12517-017-3202-y

Gubin, I. E. (1960). Regularities of Seismic Manifestations on the Territory of Tajikistan. Publishing House of the Academy of Sciences of the USSR, $634 \mathrm{p}$.

Guo, C., Montgomery, D. R., Zhang, Y., Wang, K., \& Yang, Z. (2015). Quantitative Assessment of Landslide Susceptibility along the Xianshuihe Fault Zone, Tibetan Plateau, China. Geomorphology, 248, 93-110.

https://doi.org/10.1016/j.geomorph.2015.07.012

Guzzetti, F., Carrara, A., Cardinali, M., \& Reichenbach, P. (1999). Landslide Hazard Evaluation: Are View of Current Technique Sand Their Application in a Multi-Scale Study, Central Italy. Geomorphology, 31, 181-216.

https://doi.org/10.1016/S0169-555X(99)0078-1

Guzzetti, F., Reichenbach, P., Ardizzone, F., Cardinali, M., \& Galli, M. (2006). Estimating the Quality of Landslide Susceptibility Models. Geomorphology, 81, 166-184.

https://doi.org/10.1016/j.geomorph.2006.04.007

Guzzetti, F., Reichenbach, P., Cardinali, M., Galli, M., \& Ardizzone, F. (2005). Probabilistic Landslide Hazard Assessment at the Basin Scale. Geomorphology, 72, 272-299. https://doi.org/10.1016/j.geomorph.2005.06.002

Kufner, S. K., Schurr, B., Ratschbacher, L., Murodkulov, S., Abdulhameed, S., Ischuk, A., Metzger, S., \& Kakar, N. (2018). Seismotectonics of the Tajik Basin and Surrounding Mountain Ranges. Tectonics, 37, 2404-2424. https://doi.org/10.1029/2017TC004812

Lee, S., \& Pradhan, B. (2007). Landslide Hazard Mapping at Selangor, Malaysia Using Frequency ratio and Logistic Regression Models. Landslides, 4, 33-41. https://doi.org/10.1007/s10346-006-0047-y

Li, L., Lan, H., Guo, C., Zhang, Y., Li, Q., \& Wu, Y. (2017). A Modified Frequency Ratio Method for Landslide Susceptibility Assessment. Landslides, 14, 727-741.

https://doi.org/10.1007/s10346-016-0771-x

Majid, S., Jagannath, A., Himan, S., \& Taher, S. (2016). Fuzzy Shannon Entropy: A Hybrid GIS-Based Landslide Susceptibility Mapping Method. Entropy, 18, Article No. 343. https://doi.org/10.3390/e18100343

Metzger, S., Ischuk, A., Deng, Z., Ratschbacher, L., Perry, M., Kufner, S. K., Bendick, R., \& Moreno, M. (2020). Dense GNSS Profiles across the Northwestern Tip of the India-Asia Collision Zone: Triggered Slip and Westward Flow of the Peter the First Range, Pamir, into the Tajik Depression. Tectonics, 39, e2019TC005797. https://doi.org/10.1029/2019TC005797

Mohadjer, S., Bendick, R., Ischuk, A., Kuzikov, S., Kostuk, A., Saydullaev, U., Lodi, S., Kakar, D. M., Wasy, A., Khan, M. A., Molnar, P., Bilham, R., \& Zubovich, A. V. (2010). Partitioning of India-Eurasia Convergence in the Pamir-Hindu Kush from GPS Measurements. Geophysical Research Letters, 37, 1-6.

https://doi.org/10.1029/2009GL041737

Mohammady, M., Pourghasemi, H. R., \& Pradhan, B. (2012). Landslide Susceptibility Mapping at Golestan Province, Iran: A Comparison between Frequency Ratio, Dempster-Shafer, and Weights-of-Evidence models. Journal of Asian Earth Sciences, 61, 221-236. https://doi.org/10.1016/j.jseaes.2012.10.005

Nikolaev, V. G. (2002). Afghan-Tajik depression: Architecture of Sedimentary Cover and Evolution. Russian Journal of Earth Sciences, 4, 399-421. https://doi.org/10.2205/2002ES000106

Paolo, M., Antonio, D., Filippo, R., \& Antonio, Z. (2008). Geomorphology and Landslide Susceptibility Assessment using GIS and Bivariate Statistics: A Case Study in Southern 
Italy. Natural Hazards, 47, 411-435. https://doi.org/10.1007/s11069-008-9230-X

Pourghasemi, H. R., Jirandeh, A. G., Pradhan, B., Xu, C., \& Gokceoglu, C. (2013). Landslide Susceptibility Mapping Using Support Vector Machine and GIS at the Golestan Province, Iran. Journal of Earth System Science, 122, 349-369. https://doi.org/10.1007/s12040-013-0282-2

Pourghasemi, H. R., Moradi, H. R., \& Aghda, S. M. F. (2013). Landslide Susceptibility Mapping by Binary Logistic Regression, Analytical Hierarchy Process, and Statistical Index Models and Assessment of Their Performances. Natural Hazards, 69, 749-779. https://doi.org/10.1007/s11069-013-0728-5

Pradhan, A. M. S., \& Kim, Y. T. (2014). Relative Effect Method of Landslide Susceptibility Zonation in Weathered Granite Soil: A Case Study in Deokjeok-ri Creek, South Korea. Natural Hazards, 72, 1189-1217. https://doi.org/10.1007/s11069-014-1065-Z

Regmi, A. D., Devkota, K. C., Yoshida, K. Pradhan, B., Pourghasemi, H. R., Kumamoto, T., \& Akgun, A. (2014). Application of Frequency Ratio, Statistical Index, and Weightsof-Evidence Models and Their Comparison in Landslide Susceptibility Mapping in Central Nepal Himalaya. Arabian Journal of Geosciences, 7, 725-742. https://doi.org/10.1007/s12517-012-0807-z

Romer, C., \& Ferentinou, M. (2016). Shallow Landslide Susceptibility Assessment in a Semiarid Environment-A Quaternary catchment of KwaZulu-Natal, South Africa. Engineering Geology, 201, 29-44. https://doi.org/10.1016/j.enggeo. 2015.12.013

Roodposhti, M. S., Rahimi, S., \& Beglou, M. J. (2014). PROMETHEE II and Fuzzy AHP: an Enhanced GIS-Based Landslide Susceptibility Mapping. Natural Hazards, 73, 77-95. https://doi.org/10.1007/s11069-012-0523-8

Rutte, D., Ratschbacher, L., Khan, J., Stübner, K., Hacker, B. R., Stearns, M. A., Enkelmann, E., Jonckheere, R., Pfänder, J. A., Sperner, B., \& Tichomirowa, M. (2017). Building the Pamir-Tibetan Plateau-Crustal Stacking, Extensional Collapse, and Lateral Extrusion in the Central Pamir: 2. Timing and Rates. Tectonics, 36, 385-419.

https://doi.org/10.1002/2016TC004294

Saaty, T. L. (1977). A Scaling Method for Priorities in Hierarchical Structures. Journal of Mathematical Psychology, 15, 234-281. https://doi.org/10.1016/0022-2496(77)90033-5.

Sadr, M. P., Maghsoudi, A., \& Saljoughi, B. S. (2014).Landslide Susceptibility Mapping of Komroud Sub-Basin Using Fuzzy Logic Approach. Geodynamics Research International Bulletin, 2, 16-28.

Santacana, N., Baeza, B., Corominas, J., de Paz, A., \& Marturia, J. A. (2003). GIS-Based Multivariate Statistical Analysis for Shallow Landslide Susceptibility Mapping in La Pobla de Lillet Area (Eastern Pyrenees Spain). Natural Hazards, 30, 281-295. https://doi.org/10.1023/B:NHAZ.0000007169.28860.80

Schwab, M., Ratschbacher, L., Siebel, W., McWilliams, M., Minaev, V., Lutkov, V., Chen, F., Stanek, K., Nelson, B., Frisch, W., \& Wooden, J. L. (2004). Assembly of the Pamirs: Age and Origin of Magmatic Belts from the Southern Tien Shan to the Southern Pamirs and Their Relation to Tibet. Tectonics, 23, 1-31.

https://doi.org/10.1029/2003TC001583

Semenov, P. G., \& Semenova, V. A. (1958). Catalogue of Earthquakes Felt on the Territory of Tajikistan for the Periods 1865-1940 and 1941-1942. Publishing House of the Tajik SSR Academy of Sciences.

Sidle, R. C., \& Ochiai, H. (2006). Landslides: Processes, Prediction, and Land Use. American Geophysical Union. https://doi.org/10.1029/WM018

Soeters, R., \& Van Westen, C. J. (1996). Slope in Stability Recognition, Analysis, and Zonation. In K. A. Turner, \& R. L. Schuster (Eds.), Landslides in Vestigation and Mitiga- 
tion, Transportation Research Board, Special Report (Vol. 247, pp. 129-177). National Academy Press.

Sørensen, R. \& Seibert, J. (2007) Effects of DEM Resolution on the Calculation of Topographical Indices: TWI and Its Components. Journal of Hydrology, 347, 79-89. https://doi.org/10.1016/j.jhydrol.2007.09.001

Trigila, A., Iadanza, C., Esposito, C., \& Scarascia-Mugnozza, G. (2015). Comparison of Logistic Regression and Random Forests Techniques for Shallow Landslide Susceptibility Assessment in Giampilieri (NE Sicily, Italy). Geomorphology, 249, 119-136. https://doi.org/10.1016/j.geomorph.2015.06.001

Vaidya, O. S., \& Kumar, S. (2006). Analytic Hierarchy Process: An Overview of Applications. European Journal of Operational Research, 169, 1-29.

https://doi.org/10.1016/j.ejor.2004.04.028

Vargas, L. G. (1990). An Overview of the Analytic Hierarchy Process and Its Applications. European Journal of Operational Research, 48, 2-8. https://doi.org/10.1016/0377-2217(90)90056-H

Viet-Ha, N., Ataollah, S., Himan, S., Sushant, K., S., Nadhir, A. A., John, J., Abolfazl, J., Wei, C., Shaghayegh, M., Jie, D., Chinh, L., Krzysztof, G., Binh, T., Huu, D., \& Baharin, B. (2020). Shallow Landslide Susceptibility Mapping: A Comparison between Logistic Model Tree, Logistic Regression, Naïve Bayes Tree, Artificial Neural Network, and Support Vector Machine Algorithms. International Journal of Environmental Research and Public Health, 17, Article No. 2749. https://doi.org/10.3390/ijerph17082749

Wang, Q. Q., Li, W. P., Chen, W., \& Bai, H. Y. (2015). GIS-Based Assessment of Landslide Susceptibility Using Certainty factor and Index of Entropy Models for the Qianyang County of Baoji city, China. Journal of Earth System Science, 124, 1399-1415. https://doi.org/10.1007/s12040-015-0624-3

Yalcin, A. (2008). GIS-Based Landslide Susceptibility Mapping Using Analytical Hierarchy Process and Bivariate Statistic Sin Ardesen (Turkey): Comparison of Results and Confirmations. CATENA, 72, 1-12. https://doi.org/10.1016/j.catena.2007.01.003

Yi, Y. N., Zhang, Z. J., Zhang, W. C., Xu, Q., Deng, C., \& Li, Q. L. (2019). GIS-Based Earthquake-Triggered-Landslide Susceptibility Mapping with Aninteg Rated Weigh Tedind Exmodelin Jiuzhaigou Region of Sichuan Province, China. Natural Hazards and Earth System Sciences, 19, 1973-1988. https://doi.org/10.5194/nhess-19-1973-2019

Yilmaz, I. (2009). Landslide Susceptibility Mapping Using Frequency Ratio, Logistic Regression, Artificial Neural Networks and Their Comparison: A Case Study from Kat Landslides (Tokat-Turkey). Computers \& Geosciences, 35, 1125-1138. https://doi.org/10.1016/j.cageo.2008.08.007

Yin, A., \& Harrison, M. (2000). Geologic Evolution of the Himalayan-Tibetan Orogen. Annual Review of Earth and Planetary Sciences, 28, 211-280.

https://doi.org/10.1146/annurev.earth.28.1.211

Zhu, A. X., Wang, R. X., Qiao, J. P., Qin, C. Z., Chen, Y. B., Liu, J., Du, F., Lin, Y., \& Zhu., T. X. (2014). An Expert Knowledge-Based Approach to Landslide Susceptibility Mapping Using GIS and Fuzzy Logic. Geomorphology, 214, 128-138.

https://doi.org/10.1016/j.geomorph.2014.02.003 